\title{
Analisis Pengaruh Kinerja Keuangan Dalam Memprediksi Pertumbuhan Laba
}

Irwan

Prodi Matematika FST,UINAM, irwan.msi@uin-alauddin.ac.id

Adnan Sauddin

Prodi Matematika FST, UINAM, Adnan.sauddin@uin-alauddin.ac.id

Ardi Iswanto

Prodi Matematika FST,UINAM, 60600114033@uin-alauddin.ac.id

\begin{abstract}
Corporate is the place of all production and gathering factors. Therefore a company's health assessment is crucial to monitoring how a company grows over the years. The purposes of this research are to determine the cause of current ratio, working capital to total asset, dept to equity ratio, and profit margin to achieve both partial and simultaneous growth of profit for sub-food and drink companies in the Indonesian stock exchange (BEI) period 2014-2018.The sample in this research is a corporate in Indonesia listed on the 2014 stock exchange through 18 corporates. The data from this research is quantitative data that obtained from the Indonesian stock exchange. A method of data analysis that utilize regression analysis. The results from the research indicate that simultaneously the CR, WCTA, DER and PM have an impact on profit growth of $94.01 \%$, and the remainder of that are $5.99 \%$ affected by other factors outside the research. Partial Current Ratio,Dept to Equity ratio, and profit margins indicate a significant impact on company growth.
\end{abstract}

Keywords: profit growth, CR, WCTA, DER, PM.

\section{PENDAHULUAN}

Dalam dunia usaha, setiap perusahaan menginginkan keuntungan yang sebesarbesarnya. Keuntungan dapat diperoleh dari berbagai faktor,salah satunya yaitu Laporan keuangan. dimana laporan keuangan sebagai informasi keuangan perusahaan. Informasi keuangan yang dimaksud adalah informasi mengenai posisi keuangan perusahaan, kinerja perusahaan, aliran kas perusahaan dan informasi lain yang berkaitan dengan laporan keuangan. Semakin baik pertumbuhan laba(keuntungan), maka semakin baik pula perusahaan tersebut. Setiap perusahaan baik badan maupun perorangan tidak dapat terlepas dari kebutuhan informasi keuangan.

Pertumbuhan laba yang terjadi pada perusahaan tidak hanya dipengaruhi oleh faktor dari jumlah investor yang berivestasi dan kondisi ekonomi, tetapi bisa dilihat dari nilai rasio keuangan juga. Dengan melihat nilai rasio keuangan yang dapat mempengaruhi terjadinya pertumbu han laba, perusahaan harus dapat mengevaluasi hasil kinerja perusahaan baik dari dalam maupun luar dengan mengelolah kewajiban, menggunakan dan memanfaatkan asset yang dimiliki nya secara tepat dan efisien dalam menghasilkan laba.

Kinerja keuangan dapat dilihat dari suatu analisis yang dilakukan untuk melihat sejauh mana suatu perusahaan telah melaksanakan keuangannya dengan menggunakan aturanaturan pelaksanaan keuangan secara baik dan benar.salah satu analisis yang menentukan ukuran sehat tidaknya operasi suatu perusahaan adalah rasio lancar, total asset turnover dan operating margin. Rasio lancar digunakan untuk melihat seberapa besar kemampuan perusahaan untuk melunasi kewajiban lancar. total asset turnover menunjukan seberapa efisien perusahaan dapat menggunakan assetnya untuk menghasilkan penjualan, dengan kata lain makin cepat asset perusahaan berputar makin besar pendapatan perusahaan tersebut.sedangkan operating profit margin untuk mengukur berapa banyak uang yang didapatkan oleh perusahaan setiap penjuaalan, sebelum pembayaran bunga pinjaman dan pajak.

Kajian mengenai prediksi pertumbuhan (perubahan) laba telah dilakukan oleh beberapa peneliti yang menghasilkan temuan yang berbeda. Warsidi dan Pramuka (2000) menemukan rasio Working Capital to Total Assets berpengaruh signifikan terhadap pertumbuhan laba. Epri (2007) menyimpulkan bahwa rasio Working Capital to Total Assets tidak berpengaruh signifikan terhadap pertumbuhan laba. Kajian oleh Epri (2007) dan Ade dan Sri (2013) menunjukkan bahwa Total Assets Turnover berpengaruh signifikan 
terhadap pertumbuhan laba, sedangkan Supriatmi dan Wahyudin (2006) menunjukkan bahwa Total Assets Turnover menyatakan hal yang sebaliknya. Kajian oleh Meythi (2005) dan Ade dan Sri (2013) menunjukkan bahwa Inventory Turnover berpengaruh signifikan terhadap pertumbuhan laba sedangkan kajian Widiasih (2006) menunjukkan hal yang sebaliknya

\section{TINJAUAN PUSTAKA}

\section{Analisis Regresi}

Analisis regresi merupakan alat analisis untuk menguji hubungan sebab akibat (kausal) antar dua variabel atau lebih, jadi analisis regresi digunakan untuk mengetahui perubahan variabel terikat (dependent variable) akibat perubahan variabel bebas (independent variable)

\section{Analisis Regresi sederhana}

Analisis regresi dilakukan apabila jenis variabelnya (variabel bebas dan variabel terikat) terdefinisi dengan jelas. Penentuan mana variabel bebas dan terikat dapat dilakukan secara empiris, atau hasil analisis yang cermat, atau hasil diskusi dengan pakar

\section{Analisis Regresi Ganda}

Analisis regresi ganda merupakan salah satu teknik analisis yang sering digunakan dalm mengolah data multivariable. Analisis regresi ganda digunakan bila penelitian bermaksud meramalkan bagaimana keadaan (naik turunnya) variabel kriterium, bila dua atau lebih variabel prediktornya dimanipulasi (sugiyono,2007:250). Jadi analisis regresi ganda akan dilakukan bila jumlah variabel preditor minimal dua. Sebagaimana uraian tersebut untuk mengetahui persamaan regresi bagi masing-masing variabel prediktor dapat dilakukan dengan cara perhitungan regresi sederhana, yakni $Y$ atas $X_{1}$ dan regresi $Y$ atas $X_{2}$

\section{Model Regresi}

MRA (Multiple Regression Analysis) digunakan untuk menguji pengaruh beberapa variabel bebas (independent variabel $=\mathrm{X}$ ) terhadap satu variabel terikat (dependent variabel $=\mathrm{Y}$ ).

Model MRA

$Y=\alpha+\beta_{1} X_{1}+\beta_{2} X_{2}+\beta_{3} X_{3}+\beta_{4} X_{4}+e$

\section{Uji Asumsi Model Regresi}

Uji asumsi untuk analisis regresi meliputi uji normalitas, multikolinieritas, heteroskedastisitas dan autoregresi.

\section{Uji Normalitas}

Uji normalitas secara formal dapat dideteksi dari metode yang dikembangkan oleh jorquebera dengan hipotesis sebagai berikut:

$$
\begin{aligned}
& \text { Skewness }=\frac{\frac{1}{n} \sum_{i=1}^{n}\left(x_{i}-\overline{\mathrm{x}}\right)^{2}}{\left(\frac{1}{n} \sum_{i=1}^{n}\left(x_{i}-\overline{\mathrm{x}}\right)^{2}\right)^{\frac{3}{2}}} \\
& \text { Kurtosis }=\frac{\frac{1}{n} \sum_{i=1}^{n}\left(x_{i}-\overline{\mathrm{x}}\right)^{4}}{\left(\frac{1}{n} \sum_{i=1}^{n}\left(x_{i}-\overline{\mathrm{x}}\right)^{2}\right)^{2}}
\end{aligned}
$$

\section{Uji Multikolenieritas}

Multikolinieritas berarti adanya hubungan linear antara variabel independen didalam model regresi. Misalkan ada dua variabel bebas $\left(\mathrm{X}_{1}, \mathrm{X}_{2}\right)$ dan $\mathrm{Y}$ variabel terikat, sehingga diperoleh :

$$
Y=\beta_{1} X_{1}+\beta_{2} X_{2}+e
$$

\section{Uji Heteroskedastisitas}

Heteroskedastisitas bertujuan menguji apakah dalam model regresi terjadi ketidaksamaan variance dan residual satu pengamatan dan pengamatan lain

\section{Uji Autokorelasi}

Autokorelasi timbul dari spesifikasi yang tidak tepat terhadap hubungan antar variabel penjelas. Keberadaan autokorelasi dapat dilihat secara kasual menggunakan lambang, yaitu:

$$
\begin{aligned}
E\left(\varepsilon_{i} \varepsilon_{j}\right) & \neq 0 ; i i \neq j \\
y & =\beta_{0}+\beta_{1} x+\varepsilon
\end{aligned}
$$

\section{Uji Signifikansi}

Baik atau buruknya regresi yang dibuat dapat dilihat berdasarkan beberapa indikator, yaitu meliputi standar error, uji hipoteis dan koefisien diterminasi $\left(R^{2}\right)$ 


\section{Uji Serentak (Uji F)}

Uji F merupakan uji keseluruhan dalam pengujian suatu regresin yaitu dengan menguji hipotesis dengan melibatkan lebih dari satu koefisien

\section{Uji Parsial (Uji t)}

Uji t ini digunakan untuk mencari ada/tidaknya perbedaan antara dua means dari dua sample/ kelompok /kategori data

\section{Koefisien Determinasi $\left(\mathbf{R}^{\mathbf{2}}\right)$}

Koefisien determinasi adalah nilai yang menunjukkan seberapa besar nilai variabel $\mathrm{Y}$ dijelaskan oleh variabel bebas $X$. Koefisien determinasi merupakan salah satu patokan yang biasanya digunakan untuk melihat suatu model regresi yang dicocokkan belum atau sudah memadai, yang dinotasikan dengan $\mathrm{R}^{2}$. Untuk menghitung $\mathrm{r}^{2}$, maka:

$$
\mathrm{Y}_{\mathrm{i}}=\hat{\mathrm{Y}}_{\mathrm{t}}+\mathrm{e}_{\mathrm{i}}
$$

\section{Laporan Keuangan}

Menurut Hanafi dan Halim (2007:49), laporan keuangan perusahaan merupakan salah satu sumber informasi yang penting di samping informasi lain seperti informasi industri, kondisi perekonomian, pangsa pasar perusahaan, kualitas manajemen dan lainnya. Ada tiga macam laporan keuangan pokok yang dihasilkan, (1) neraca, (2) laporan laba rugi, (3) laporan aliran kas

\section{Tujuan Laporan Keuangan}

Tujuan laporan keuangan adalah untuk memberikan informasi kepada pihak yang membutuhkan tentang kondisi suatu perusahaan. Menurut Standard Akuntansi Keuangan (Ikatan Akuntan Indonesia, 1994) dalam Fahmi (2014:6) bahwa tujuan laporan keuangan adalah menyediakan informasi yang menyangkut posisi keuangan, kinerja serta perubahan posisi keuangan suatu perusahaan yang bermanfaat bagi sejumlah besar pemakai dalam pengambilan keputusan ekonomi

\section{Analisis Laporan Keuangan}

Laporan sumber dan penggunaan dana diolah dari dua periode laporan keuangan. Laporan ini merupakan pelengkap laporan yang sudah ada yaitu neraca dan laporan laba rugi

\section{Analisis Rasio Keuangan}

Rasio keuangan merupakan kegiatan membandingkan angka-angka yang ada dalam laporan keuangan dengan cara membagi satu angka dengan angka lainnya. Menurut Kasmir (2014:104)

\section{Pertumbuhan Laba}

Laba merupakan informasi perusahaan paling diminati dalam pasar uang. Menentukan dan menjelaskan laba suatu usaha pada satu periode merupakan tujuan utama laporan laba rugi (Subramanyam dan Wild, 2013:109). Pertumbuhan laba dihitung dengan cara mengurangkan laba periode sekarang dengan laba periode sebelumnya kemudian dibagi dengan laba pada periode sebelumnya (Harahap, 2016:310)

\section{Variabel dan Definisi Operasional Variabel}

1. Pertumbuhan laba $(\hat{Y})$,

$$
\Delta \hat{Y}_{i t}=\frac{\left(\hat{Y}_{t}-\hat{Y}_{t-1}\right)}{\hat{Y}_{t-1}}
$$

2. Current Ratio $\left(\mathrm{X}_{1}\right)$ rasio ini membandingkan aktiva lancar dengan hutang lancar.

$$
\mathrm{CR}=\frac{\text { Aktiva Lancar }}{\text { Hutang Lancar }}
$$

\section{Working Capital to Total Asset Ratio}

Working capital to total asset ratio adalah ukuran bersih pada aktiva lancar perusahaan terhadap modal perusahaan.

$$
\text { WCTA }=\frac{\text { ASSET LANCAR-UTANG LANCAR }}{\text { TOTAL ASSET }}
$$

\section{Debt to Equity Ratio}

Rasio solvabilitas yang digunakan adalah Debt to Equity Ratio (DER). Debt to Equity Ratio adalah rasio yang digunakan untuk menilai utang dan ekuitas. Rasio ini berguna untuk mengetahui jumlah dana yang disediakan peminjam (kreditor) dengan pemilik perusahaan atau berfungsi untuk mengetahui setiap rupiah modal sendiri yang dijadikan untuk jaminan utang. 


$$
\mathrm{DR}=\frac{\text { TOT AL LIABILITAS }}{\text { TOTAL EQUITY }}
$$

\section{Profit Margin}

Rasio profitabilitas yang digunakan dalam penelitian ini adalah Profit Margin Ratio atau Rasio Margin Laba terhadap Penjualan. Profit Margin Ratio (PM) adalah salah satu rasio yang digunakan untuk mengukur margin laba atas penjualan.Rasio ini menunjukkan pendapatan bersih perusahaan atas penjualan.

$$
\mathrm{PM}=\frac{\text { lABA SETELAH PAJAK }}{\text { PENJUALAN }}
$$

\section{METODOLOGI}

Penelitian dilakukan dengan menggunakan data - data perusahaan manufaktur sektor industri barang konsumsi yang terdaftar di Bursa Efek Indonesia (BEI). Data yang digunakan yaitu data tahun Periode 2015 sampai 2018

\section{Teknik Analisis}

Teknik analisis yang digunakan adalah analisis regresi, dengan langkah-langkah sebagai berikut :

1. Melakukan analisis deskriptif

2. Menentukan model regresi berganda

3. Menguji asumsi model regresi
a. Uji Normalitas
b. Uji Multikolinearitas
c. Uji Autokorelasi
d. Uji Heteroskedastisitas

4. Memeriksa parameter regresi berganda (Uji Statistik)

\section{PEMBAHASAN}

\section{Model Regresi Terbaik}

Setelah melakukan analisis menggunakan Program R maka didapat model regresi yaitu

$$
\begin{gathered}
Y=-8.564809+0.327695 X_{1}+0.002768 \\
X_{2}+1.585718 X_{3}+0.605430 X_{4}+\varepsilon
\end{gathered}
$$

Pemilihan model regresi terbaik, menggunakan Stepwise regression. Untuk kasus pertumbuhan laba. Diperoleh model regresi terbaik yang dapat ditulis sebagai berikut :

$$
\begin{aligned}
Y= & -8.564809+0.327695 X_{1}+ \\
& 1.585718 X_{3}+0.605430 X_{4}+\varepsilon
\end{aligned}
$$

Dari analisis pemilihan model regresi terbaik menggunakan Stepwise diketahui bahwa hanya variable $\mathrm{X}_{2}$ (Working Capital to total Assets) saja yang tidak memberikan pengaruh dalam memprediksi pertumbuhan laba.

\section{Uji Asumsi Klasik \\ Uji Normalitas}

Uji Normalitas digunakan untuk mengetahui apakah data tersebut bersifat normal atau tidak dengan hipotesis :

$\mathrm{H}_{0}=$ Data berdistribusi Normal

$\mathrm{H}_{1}=$ data tidak berdistribusi Normal

Tabe1. Hasil Pengujian Normalitas

\begin{tabular}{cc}
\hline $\mathrm{W}$ & $\mathrm{p}$-value \\
\hline 0.94479 & 0.3492 \\
\hline
\end{tabular}

Dapat dilihat dari Tabel diatas dengan taraf signifikan $\alpha=0.05$ maka nilai $\mathrm{P}$-value $>\alpha$, maka $\mathrm{H}_{0}$ diterima, yang berarti bahwa model regresi yang terpilih berdistribusi normal.

\section{Uji Multikolinieritas}

Pengujian ini untuk mengetahui apakah ada hubungan yang signifikan antar variabel bebas. Pengujian ini dapat dilakukan dengan melihat nilai Vif (Varians Inflation Faktors). Jika nilai Vif $>10$ maka terjadi multikolinieritas dan sebaliknya jika nilai Vif $<10$ maka tidak terjadi multikolinieritas.

Tabel 2. Nilai VIF untuk setiap variabel

\begin{tabular}{ccccc}
\hline & $\mathrm{X}_{1}$ & $\mathrm{X}_{2}$ & $\mathrm{X}_{3}$ & $\mathrm{X}_{4}$ \\
\hline $\begin{array}{c}\text { Pertumbuhan } \\
\text { Laba }\end{array}$ & 1.195 & 1.025 & 1.22 & $\begin{array}{c}1.0 \\
7\end{array}$ \\
\hline
\end{tabular}

Tabel diatas menunjukkan bahwa variabel $\mathrm{X}_{1}$, $\mathrm{X}_{2}, \quad \mathrm{X}_{3}, \quad$ dan $\mathrm{X}_{4}, \quad$ tidak terjadi multikolinieritas.karena nilai VIF tidak lebih besar dari 10.

\section{Uji Heteroskedastisitas}

Uji ini bertujuan untuk menguji apakah dalam model regresi terjadi ketidaksamaan variansi dari residual satu pengamatan ke pengamatan lain dengan menggunakan uji Breusch-Pagan. 
Tabel 3. Nilai statistik Uji Breusch-Pagan.

\begin{tabular}{ccc}
\hline BP & Df & P-Value \\
\hline 4.2996 & 4 & 0.367 \\
\hline
\end{tabular}

Dapat dilihat bahwa Nilai P-value yaitu 0.7319. ini menunjukkan nilai $\mathrm{P}-$ value $>0.05$. maka $\mathrm{d}$ ari itu $\mathrm{H}_{0}$ ditolak. Sehingga dapat disimpulkan $\mathrm{b}$ ahwa variansi redisual adalah konstan.

\section{Uji Autokorelasi}

Uji autokorelasi bertujuan untuk mengetah ui adanya autokorelasi dari regresi dengan meng gunakan Uji Durbin-Watson. Dikatakan tidak te rdapat autokorelasi jika nilai DW $>$ du dan (4-D W) $>$ dl.

Tabel 4. Nilai statistik Uji Durbin-Watson

\begin{tabular}{cccc}
\hline $\begin{array}{l}\text { Durbin- } \\
\text { Watson }\end{array}$ & P-Value & $\mathrm{Dl}$ & $\mathrm{Du}$ \\
\hline 2.3307 & 0.81 & 1.50 & 1.73 \\
\hline
\end{tabular}

Dapat dilihat bahwa nilai Durbin Watson adalah $\mathrm{dw}=2.3307$ ini menunjukkan bahwa nilai $\mathrm{dw}>\mathrm{d}$ u yaitu $2.3307>1.7366 \mathrm{dan}(4-\mathrm{dw})>\mathrm{dl}$ yang ar tinya tidak terjadi autokorelasi.

\section{Uji Signifikansi Model dan Uji Parameter}

\section{Uji F}

Uji $\mathrm{F}$ digunakan untuk mengetahui pengar uh variable bebas secara bersama (simultan) ter hadap variable terikat.

Tabel 5. Nilai statistik Uji F

\begin{tabular}{cccc}
\hline Df1 & Df2 & $\begin{array}{c}\text { Taraf } \\
\text { Signifikan }\end{array}$ & $\begin{array}{c}\text { Nilai Kritis } \\
\text { F }\end{array}$ \\
\hline 4 & 13 & 0.05 & 3.18 \\
\hline
\end{tabular}

Berdasarkan Tabel diatas diketahui bahwa nilai statistic dari Uji $\mathrm{F}$ adalah 67.69. dengan nilai de rajat bebas pembilang 4 dan nilai derajat bebas penyebut adalah 13 . Nilai kritis $F$ dengan deraja t bebas pembilang 4 , derajat bebas penyebut 13 , dan tingkat signifikansi 5\% adalah 3.18(dilihat Pada Tabel F). f hitung > f table maka variabel bebas terbukti secara bermakna mempengaruhi variabel terikat.

\section{Uji T}

Uji T digunakan untuk menguji secara par sial masing-masing Variabel . hasil Uji T dapat diketahui pada table coefficients pada kolom sig nifikan, jika $\mathrm{T}$ hitung $>\mathrm{T}$ tabel maka dapat dika takan bahwa terdapat pengaruh antara variabel bebas terhadap variable terikat secara persial.

\begin{tabular}{cc}
\multicolumn{2}{c}{ Tabel 6. Nilai t-hitung } \\
\hline Model & t-hitung \\
\hline $\mathrm{X}_{1}$ & 4.451 \\
$\mathrm{X}_{2}$ & 0.410 \\
$\mathrm{X}_{3}$ & 13.540 \\
$\mathrm{X}_{4}$ & 6.389 \\
\hline
\end{tabular}

Dapat dilihat bahwa nilai statistik dari uji $\mathrm{t}$ untu $\mathrm{k}$ Current ratio $\mathrm{t}$ hitung $=4.451>\mathrm{t}$ Table $=2.1$ 6037 (table t) maka $\mathrm{H}_{0}$ diterima.working capita 1 to total asset $\mathrm{t}$ hitung $=0.410<\mathrm{t}$ Table $=2.1603$ 7 maka $\mathrm{H}_{0}$ ditolak. dept to equity ratio $\mathrm{t}$ hitung $=$ $13.540>\mathrm{t}$ Table $=2.16037$ maka $_{0}$ diterima . profit margin $\mathrm{t}$ hitung $=6.389>\mathrm{t}$ Table $=2.16$ 037 maka $\mathrm{H}_{0}$ diterima.

\section{Uji Adjusted R Square}

Tabel 7. Nilai Adjusted R Square

\begin{tabular}{cccc}
\hline R & $\begin{array}{c}\text { R } \\
\text { Square }\end{array}$ & $\begin{array}{c}\text { Adjusted } \\
\text { R Square }\end{array}$ & $\begin{array}{c}\text { Std. Error } \\
\text { of the } \\
\text { estimate }\end{array}$ \\
\hline 0.910 & 0.954 & 0.940 & 1.808 \\
\hline
\end{tabular}

Pada Table dapat dilihat bahwa nilai adjusted $R$ square sebesar 0.93401 hal ini menunjukk an bahwa konstribusi setiap variabel $\mathrm{X}_{1}, \mathrm{X}_{2}, \mathrm{X}_{3}$, dan $\mathrm{X}_{4}$, mempengaruhi Pertumbuhan laba atau $\mathrm{s}$ ebesar $94,01 \%$.

\section{Pembahasan}

Berdasarkan data keuangan Perusahaan yang dianalisis menunjukkan hasil pengujian statistic yaitu terdapat 4 variabel bebas dan satu variabel terikat.

Adapun persamaan model matematikanya adalah :

$Y=-8.564809+0.327695 X_{1}+0.002768 X_{2}+1.585718$

$$
\mathrm{X}_{3}+0.605430 \mathrm{X}_{4}
$$

Dari model tersebut diperoleh nilai koefisien dari Current Ratio sebesar 0.327695 atau $32,76 \%$ yang bernilai positif. Artinya setiap kenaikan satu satuan dari Current Ratio maka Perubahan Laba akan bertambah sebesar $33,71 \%$. Kemudian nilai koefisien Working Capital to total assets sebesar 0.002768 atau $0,27 \%$ yang bernilai positif, artinya setiap 
kenaikan satu satuan Working Capital to total assets maka Perubahan Laba akan bertambah sebesar $0,27 \%$. nilai koefisien Dept to equity ratio sebesar 1.585718 atau $158 \%$ yang bernilai positif. Kemudian variabel Profit margin sebesar 0.605430 atau $60,54 \%$ yang bernilai positif, artinya setiap kenaikan satu satuan Profit margin maka Perubahan laba akan bertambah sebesar 60,54\%\% dengan asumsi bahwa variabel bebas yang lain dari model regresi adalah tetap.dan kemudian nilai konstanta sebesar -8.564809 artinya apabila variabel lain bernilai kontanta maka nilai Perubahan Laba akan berubah dengan sendirinya sesuai nilai konstantanya.

Dari hasil analisis dapat disimpulkan bahwa variabel berkonstribusi besar terhadap pertumbuhan laba. Dan semakin kecil nilai Standar Error of Estimate maka semakin tepat prediksi yang dilakukan dalam menjelaskan pengaruh variabel independent terhadap variabel dependen.

\section{KESIMPULAN}

Penelitian ini mencoba untuk menjawab tujuan penelitian, yaitu untuk menganalisis pengaruh Kinerja Keuangan terhadap Pertumbuhan Laba. Hasil pengujian hipotesis dengan menggunakan analisis regresi berganda dengan empat variabel independen ( $\mathrm{CR}$, WCTA, DER, dan PM) dan satu variabel dependen yakni Pertumbuhan Laba menunjukkan bahwa ada tiga variable yang berpengaruh secara signifikan terhadap pertumbuhan laba yaitu current ratio (CR) diperoleh nilai sebesar 0.327695 atau $32,76 \%$, Debt to equity ratio (DER) diperoleh nilai sebesar 1.585718 atau $158 \%$, Profit Margin (PM) diperoleh nilai sebesar 0.605430 atau $60,54 \%$ dan satu variable yang tidak berpengaruh secara signifikan namun berpengaruh secara simultan terhadap pertumbuhan laba, diperoleh nilai sebesar 0.002768 atau $0,27 \%$.

\section{DAFTAR PUSTAKA}

[1] Hadi, S., Gunawan, I., \& DALLE, J. (2018). Statistika Inferensial Teori dan Aplikasinya.

[2] Gujarati, D. N. (2004). Basic Econometrics 4th Edition. Tata McGrawHill (pp. 1-1003).

[3] Harahap, S. S. (2002). Teori Akuntansi Laporan Keuangan.

[4] Ifada, L. M., \& Puspitasari, T. (2016). Analisis pengaruh rasio keuangan terhadap perubahan laba. Jurnal Akuntansi dan Auditing, 13(1), 97-108.

[5] Irianto, A. P. D. (2004). Statistik konsep dasar \& aplikasinya.

[6] Misbach, I. (2013). Pengantar Statistik Sosial.

[7] Sari, L. P., \& Widyarti, E. T. (2015). Analisis Pengaruh Rasio Keuangan terhadap Pertumbuhan Laba (Studi Kasus: Perusahaan Food and Beverages yang terdaftar di Bursa Efek Indonesia periode 2009 sampai dengan 2013). Diponegoro Journal Of Management, 680-690.

[8] Setiawan, D. I. (2016). Analisis Pengaruh Kinerja Keuangan Bank, Tingkat Inflasi dan Bi Rate Terhadap Pertumbuhan Laba (Studi Pada Bank Swasta Devisa yang Terdaftar Pada Bursa Efek Indonesia Periode 2009-2013). Journal of Accounting and Business Studies, 1(1).

[9] Siregar, S. (2005). Statistik terapan untuk penelitian. Jakarta: PT Gramedia Widiasarana Indonesia.

[10] Supranto, J. (2009). Statistik teori dan aplikasi edisi ketujuh. Jakarta: Erlangga.

[11] Widarjono, A. (2007). Ekonometrika: teori dan aplikasi untuk ekonomi dan bisnis. Yogyakarta: Ekonisia.

[12] Rachmatika, A. G. (2019). PENGARUH RASIO KEUANGAN TERHADAP PERTUMBUHAN LABA PADA PERUSAHAAN SUB SEKTOR PERKEBUNAN DI BURSA EFEK INDONESIA PERIODE 2013-2017. eJurnal Adsminitrasi Bisnis, ISSN 2355, 5408.

[13] Djannah, R., \& Triyonowati, T. (2017). PENGARUH KINERJA KEUANGAN 
TERHADAP PERTUMBUHAN LABA PADAPERUSAHAAN FOOD AND BEVERAGES. Jurnal Ilmu dan Riset Manajemen (JIRM), 6(7).

[14] Meilyanti. (2017). Analisis Pengaruh Rasio Keuangan Terhadap Pertumbuhan Laba Pada Sub Sektor Makanan Dan Minuman Di Bursa Efek Indonesia Periode 2012-2016. EJournal Administrasi Bisnis, 5(4), 1000-1013.

[15] Prasanti, T. A., Wuryandari, T., \& Rusgiyono, A. (2015). Aplikasi regresi data panel untuk pemodelan tingkat pengangguran terbuka Kabupaten/Kota di Provinsi Jawa Tengah. Jurnal Gaussian, 4(3), 687-696.

[16] Melati, P. M., \& Suryowati, K. (2018). Aplikasi Metode Common Effect, Fixed Effect, dan Random Effect untuk Menganalisis Faktor-Faktor yang Mempengaruhi Tingkat Kemiskinan Kabupaten/Kota di Jawa Tengah dan Daerah Istimewa Yogyakarta. Jurnal Statistika Industri dan Komputasi, 3(01), 41-51.

[17] Rahmadeni, R., \& Yonesta, E. (2016). Analisis regresi data panel pada pemodelan produksi panen kelapa sawit di kebun sawit plasma Kampung Buatan Baru. Jurnal Sains Matematika dan Statistika, 2(1), 11-22.

[18] Sari, D. P., Paramu, H., \& Utami, E. S. (2017). Analisis Pengaruh Rasio Keuangan dan Ukuran Aset Pada Pertumbuhan Laba Perusahaan Manufaktur Yang Terdaftar Pada Bursa Efek Indonesia Periode 2010-2013. EJournal Ekonomi Bisnis Dan Akuntansi, 4(1), 63. https://doi.org/10.19184/ejeba.v4i1.4578 